\title{
Grading as a progressive technology for managing financial incentives of employees
}

\author{
Karine Barmuta ${ }^{1 *}$, Asiyat Tagibova ${ }^{2}$, and Aleksandra Prikhodko ${ }^{3}$ \\ ${ }^{1}$ Don State Technical University, 344002, Rostov-on-Don, Russia \\ ${ }^{2}$ Moscow State Institute of International Relations (MGIMO), 119454, Moscow, Russia \\ ${ }^{3}$ Saint Petersburg State University of Architecture and Civil Engineering, 190005, Saint Petersburg, \\ Russia
}

\begin{abstract}
One of the most efficient ways to financially motivate personnel is grading, which is conducted using a number of stages of grading system development and implementation. The grading mechanism is considered, the job evaluation is carried out according to the selected factors using the example of the specific company. Thesummary analysis of the research results is provided in the article. According to the conclusions, the use of grading contributes to theefficiency increase of staff motivation, which ultimately leads to the increased labor productivity.
\end{abstract}

\section{Introduction}

In the contemporary era of market economy ongoing development in Russia, the activities of any company should include continuous analysis and assessment of the efficiency of resource use, including personnel as a special and essential strategic factor in the country's transition to the innovative development $[1,2]$.

Many approaches to determining the efficiency of personnel management can be found in the economic literature, however, the generally accepted methodology was not developed in domestic or world practice [3, 4].

Personnel management system evaluation should be conducted for its functional subsystems using a number of indicators, which will allow to describe this systemin a comprehensive manner from the perspective of system approach [5].

As a rule, the key element of staff motivation is financial incentives, but such an important aspect as moral climate in a company, its social environment taking into account the specificity of human resources should not be forgotten. From this perspective, the staff also needs development, motivation to achieve the required results, adjustment to the working environment, etc. It is the staff motivation that is currently being disaggregated and, in comparison with the traditional Soviet-era principles, the set of motives for each local employee of the company has now considerably expanded, since the basic mix of employee needs has been changed, the very nature of work is being rebuilt, and the tactical and strategic purposes of an enterprise are being adjusted. The consequences of such

${ }^{*}$ Corresponding author: carinaba@yandex.ru 
changes mostly include new tools and techniques of personnel motivation (innovations) in business structures and in the social, political, economic life of thecountry as a whole.

As a result of the development of market relations, such events as the participation in the World Trade Organization, opening of representative offices of foreign organizations, labor migration led to the evolution of labor management. The effect of adjustment to the current situation includes the increased competition for highly skilled human capital, and, as a consequence, there are new tools for staff motivation. For instance, the system of grade levels can be considered one of such tools that has been developing in Russia since the beginning of the XX century. Let us present a brief characteristic of "grade" term for the detailed description of this system.

The study of current economic literature makes it possible to formulate the essence of the term "grade" as a fixed range of "weights", within which the posts have the identical status and the same tariff range of labor remuneration. With this, the set of grades is basically a system of grades, which is presented as a salary scale or a wage scale when using predetermined factors.

Currently, the grading system most effectively covers the totality of business processes, employee remuneration (its basic part) and is able to correspond with the staff motivation system[6].

The tasks shown in Figure 1 can be considered as the tasks that grading helps to solve in certain organizations.

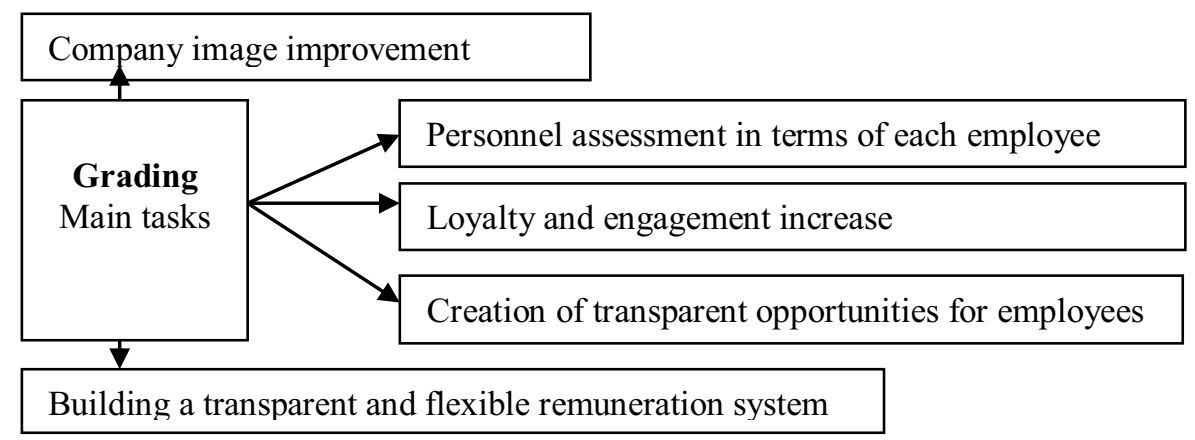

Fig. 1. The main tasks solved with the use of grading

Grading is a set of procedures for determining and evaluating the ranking of posts, when they are divided into the corresponding grades in accordance with their importance to the organization. In other words, grading is the technology for grading system development. It is important to note further that the grading system turned out to be efficient and applicable almost worldwide, in all countries and is rightfully considered a worthy basis for the development of a transparent and adjustable personnel remuneration system. Grading came to Russia in the 1960s to replace the Soviet-era wage scale, which in practice turned out to be somewhat cumbersome for organizations in the conditions of rapidly evolving realities of the country's economy as a whole. The weak points of the previous tariff scale turned out to be the lack of transparency, the lack of economic logic and certain rigidity of the organizational structure. For example, it was necessary to formally indicate the post of the employee, for instance, "engineer of the $i$-th category", just to determine his salary [8].

Grading makes it possible to flexibly organize the post levels in the form of a scheme, taking into account not only qualification, but also other important factors according to their areas of responsibility, level of complexity of decisions made, etc. Under the grading rules, each post has its place in the ranking and receives a corresponding grade in the salary range $[9,14]$. 


\section{Materials and methods}

Particular attention should be paid to the issue of salary system development based on grades. Grading experts suggest a different number of stages for grading system development methodology in a company $[13,15]$.

Based on the theoretical and empirical analysis carried out by the authors, the following main stages of grading system development and implementation in an organization are proposed (Table 1).

Table1. The stages of development and implementation of company's grading system

\begin{tabular}{|c|c|c|}
\hline Number & Stages & Description \\
\hline 1 & $\begin{array}{c}\text { Formation of a working } \\
\text { committee on job } \\
\text { evaluation }\end{array}$ & $\begin{array}{l}\text { The committee includes a working group, an expert } \\
\text { commission and experts }\end{array}$ \\
\hline 2 & $\begin{array}{l}\text { Development of the job } \\
\text { evaluation methodology }\end{array}$ & $\begin{array}{l}\text { - drawing up lists of reimbursable factors; } \\
\text { - development of scales (degree of intensity of } \\
\text { factors); } \\
\text { - distribution of points by groups of factors }\end{array}$ \\
\hline 3 & $\begin{array}{l}\text { Assessment of the value of } \\
\text { work }\end{array}$ & $\begin{array}{l}\text { - job analysis and description; } \\
\text { - assessment of the value of work; } \\
\text { - processing the results of assessment of the value } \\
\text { of work }\end{array}$ \\
\hline 4 & $\begin{array}{l}\text { Grading system } \\
\text { development }\end{array}$ & $\begin{array}{l}\text {-identification of the number of grades; } \\
\text { - } \\
\text { determinationoftheminimumandmaximumsalaryforea } \\
\text { chgrade }\end{array}$ \\
\hline 5 & $\begin{array}{l}\text { Grading system } \\
\text { implementation }\end{array}$ & $\begin{array}{l}\text { - holding a general meeting of employees in order } \\
\text { to inform them about the implementation of the } \\
\text { grading system in the enterprise; } \\
\text { - preparation of information systems for grading } \\
\text { system implementation; } \\
\text { - carrying out organizational arrangements within } \\
\text { structural units }\end{array}$ \\
\hline
\end{tabular}

Let us describe each stage of grading system development in a company from the perspective of the integrated system approach.

Development and implementation of grades in a company is a complex and multifaceted process that requires great attention of a full group of specialists. Thus, it is important to form a working committee for job evaluation in the process of development and implementation of company's grading system. It should be noted that it is the expert commission, which should include professionals with relevant work experience, that rank and evaluate the importance of the factors.

The high adaptability of the grading system is explained by the fact that the set of assessed factors is formed according to the specifics of company's activities, based on economic, social, natural, and other conditions that arise both in the internal and external environment of any organization. Therefore, it is important to take into account both domestic and foreign experience of grading use when developing and implementing a grading system in a company. As a rule, the following factors can be used for grading system development: knowledge, experience, problem-solving skills, competence, responsibility, initiative, working conditions, labor intensity, communication skills, management skills, role in project performance, etc.

Let us consider the content of this and subsequent stages with regard to the grading system development for engineers of design and technological department of PAO 
"Shakhtinskiy zavod Gidroprivod" (Shakhty plant, PAO "SZG"). A brief description of this enterprise is as follows. PAO "SZG" was established in 1971 by several individuals with the authorized capital in the amount of 457990 rubles. The plant is engaged in the production of axial-piston hydraulic machines and radial-piston pumps. The consumers of PAO "SZG"products are enterprises located in different regions of Russia and abroad. The structure of the design andtechnological department of the enterprise is shown in Figure 2.

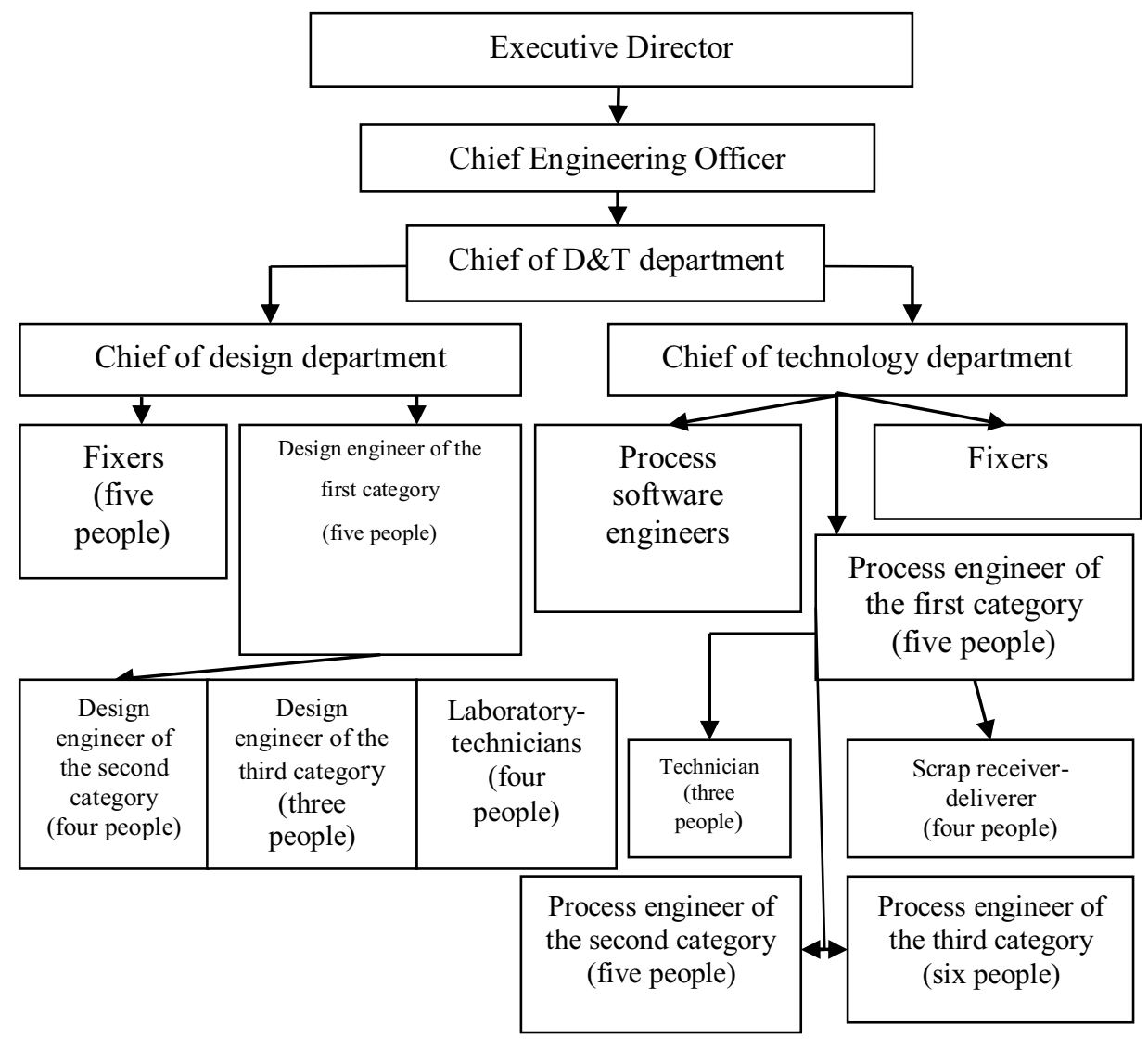

Fig. 2. The organizational structure of design andtechnological (D\&T) department of PAO "SZG"

The following factors were selected to develop the company's grading system:

1.personnel management;

2. responsibility;

3. independence of work;

4. experience;

5. level of expertise (qualification);

6. level of contact;

7. complexity of work;

8. cost of a mistake.

According to the data in Figure 2, for each of the above eight evaluated factors, a scale of values is developed, which shows the nature of the work performed and reflects the increase in their level of complexity.

The scale of values for the evaluated factors with regard to D\&T department of PAO "SZG" is shown in Figure 3, which presents the example of description of "Personnel management" factor levels. 


\begin{tabular}{|c|c|}
\hline Factors: & Description of levels \\
\hline Personnel management & $\begin{array}{c}\text { A - there are no subordinates, i.e. there is no need for } \\
\text { personnel management }\end{array}$ \\
\hline \multicolumn{2}{|l|}{ Responsibility } \\
\hline Independence of work & \multirow[t]{2}{*}{$\begin{array}{l}\text { B - there are no direct subordinates, periodic } \\
\text { coordination of the work of other employees } \\
\text { according to the task }\end{array}$} \\
\hline Experience & \\
\hline Qualification & $\begin{array}{l}\mathrm{C} \text {-coordination of working group activities } \\
\qquad(2-3 \text { people })\end{array}$ \\
\hline Level of contact & $\begin{array}{l}\text { D-managing the group of subordinates for regular } \\
\text { performance of functional tasks }\end{array}$ \\
\hline Complexity of work & \multirow{2}{*}{$\begin{array}{l}\text { E-management of unit (vertical and horizontal } \\
\text { communication) }\end{array}$} \\
\hline \multirow[t]{2}{*}{ Cost of a mistake } & \\
\hline & $\mathrm{F}$-management of group of units \\
\hline
\end{tabular}

Fig. 3. The scale of values for the evaluated factors for D\&T departmentofPAO "SZG"

Thus, the scale of values for the selected factors presented in Figure 3 for PAO "SZG" company consists of six levels A, B, C, D, E, F. The distribution of points is conducted in ascending order from 1 to 6 , where 1 point is assigned to level $\mathrm{A}$ and 6 points - to level $\mathrm{E}$ respectively.

\section{Results}

As a rule, the grading system implementation in a company involves compilation of a resulting table with job evaluation by selected factors, which, in turn, are divided into levels, and points are distributed on an incremental basis. Thus, according to the grading rules for PAO "SZG", the job evaluation for design engineer of the first category is conducted and the results are shown in Table 2.

Table 2. Job evaluation of design engineer (of the first category) by factors inPAO "SZG"

\begin{tabular}{|l|l|c|c|c|c|c|c|c|}
\hline \multirow{2}{*}{$\begin{array}{c}\text { Factors of } \\
\text { evaluation }\end{array}$} & \multicolumn{5}{|c|}{ Scale of values (in points) } & $\begin{array}{c}\text { Importance } \\
\text { (5-point } \\
\text { scale) }\end{array}$ & $\begin{array}{c}\text { Total } \\
\text { score for } \\
\text { the factor }\end{array}$ \\
\hline $\begin{array}{l}\text { Personnel } \\
\text { management }\end{array}$ & & & & + & & & 5 & 20 \\
\hline Responsibility & & & + & & & & 5 & 15 \\
\hline $\begin{array}{l}\text { Independence of } \\
\text { work }\end{array}$ & & + & & & & & 5 & 10 \\
\hline Experience & & & & + & & & 5 & 20 \\
\hline
\end{tabular}




\begin{tabular}{|l|l|l|l|l|l|l|l|l|}
\hline $\begin{array}{l}\text { Level of } \\
\text { expertise } \\
\text { (qualification) }\end{array}$ & & & & + & & & 5 & 20 \\
\hline Level of contact & + & & & & & & 5 & 5 \\
\hline $\begin{array}{l}\text { Complexity of } \\
\text { work }\end{array}$ & & & + & & & & 5 & 15 \\
\hline Cost of a mistake & & + & & & & 5 & 10 \\
\hline
\end{tabular}

Thus, the total score of the post evaluation of design engineer of the first category by factors amounts to 115 points. Scoring the posts analyzed is carried out according to the staffing table of D\&T department. It should be noted that the selected factors are ambivalent, and distinction is required using importance weights, which determine the importance of a particular factor regarding other factors. In this case, the weight of all factors is taken as $100 \%$. Figure 4 shows the horizontal and vertical calculation of points for company's posts.

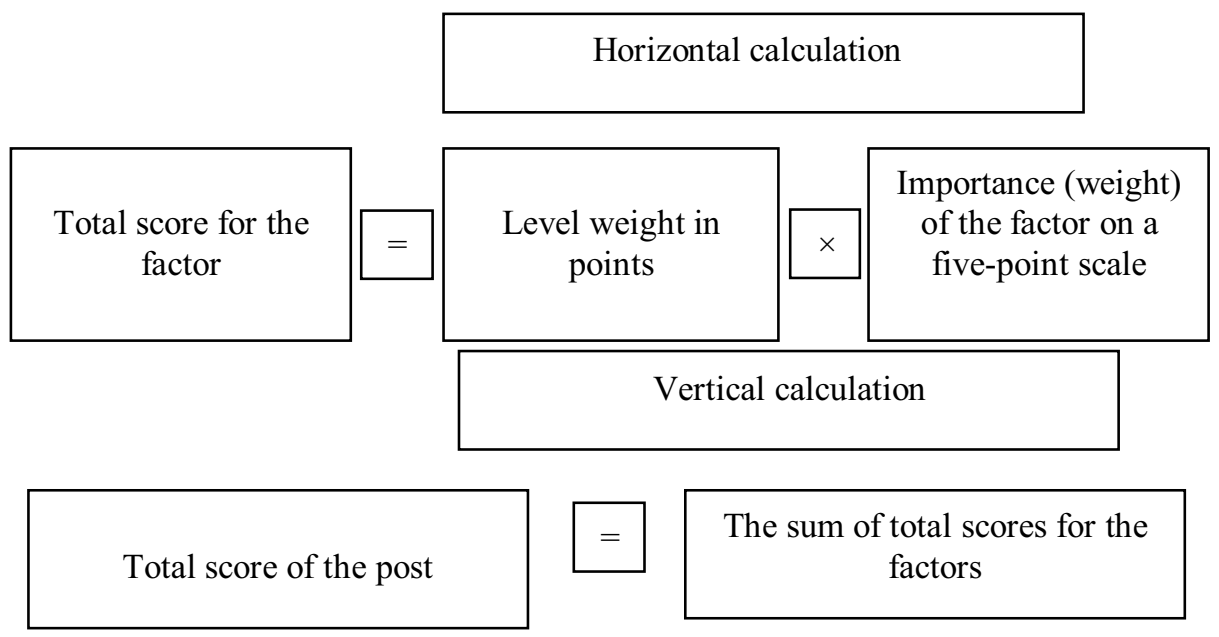

Fig. 4. The scheme of horizontal and vertical calculation of points for company's posts

Following the calculations in Figure 4 points were obtained for the evaluated posts. These posts were arranged in a sequence according to the hierarchy, and then they were divided into groups, the so-called grades. The calculation of total scores for the posts of D\&T departmentof PAO "SZG"made it possible to distribute the points as presented in Table 3.

Table 3. Distribution of obtained points by grades for PAO "SZG"

\begin{tabular}{|l|c|c|c|}
\hline Grade number & Score range & Grade number & Score range \\
\hline 1 grade & $6-20$ points & 9 grade & $126-140$ points \\
\hline 2 grade & $21-35$ points & 10 grade & $141-155$ points \\
\hline 3 grade & $36-50$ points & 11 grade & $156-170$ points \\
\hline 4 grade & $51-65$ points & 12 grade & $171-185$ points \\
\hline 5 grade & $66-80$ points & 13 grade & $186-200$ points \\
\hline 6 grade & $81-95$ points & 14 grade & $201-215$ points \\
\hline 7 grade & $96-110$ points & 15 grade & $216-230$ points \\
\hline 8 grade & $111-125$ points & 16 grade & $231-240$ points \\
\hline
\end{tabular}


The detailed review of the organizational structure of PAO "SZG" leads to the conclusion that this company has the following departments: HR department, management, financial and economic planning departments, accounting department, production department, commercial and sales departments, legal department, department of information technology, etc. It is also necessary to categorize the posts of the company, for example, the categories may be as follows: management personnel, specialists, direct workers, auxiliary workers, service staff.

The final and necessary stage of the grading systemdevelopment includes the establishment of official salaries and calculation of salary ranges. It should be noted that calculation of official salaries is conducted according to the results of scoring. It is necessary to select a number of posts in each grade, for which the relevant parameters of the specific post in the labor market should be taken into account and the need for compensatory financial incentives for a givenpost should be identified [17,18].

Before determining the official salaries for the company, it is necessary to analyze information about the market value of a given job. Moreover, it is essential to take into account the financial situation of the enterprise, corporate personnel policy and other factors that influence decision-making. Thus, to make a better management decision and coordinate it with the chief financial officer of the enterprise it is required to explore the labor market and estimate the average value (salary) of the identical post in other companies[19, 20].

Accordingly, it is possible to establish a salary range for each grade, which is established not for a single post, but for the entire grade. For instance, the lower limit of the salary range corresponds to the minimum official salary, and, in fact, it should also correspond to the average value of the given post in the labor market. However, it should be kept in mind that a company that does not have large financial turnover, is not able to set a higher minimum official salary than the average minimum salary in the market.

\section{Conclusions}

Detailed study of the grading process leads to the conclusion that the established official salary is characterized by the importance and value of the post itself, but not by the employee's efficiency, therefore, it seems possible to establish the salary range for each grade. The salary range depends directly on the financial situation of the company, system of personnel motivation and development, which means that in most cases it has a constant value. That is, the employees will receive remuneration for the performance of their job duties at a "normal" rate in the amount of basic financial incentive.

If the value of the average market salary is set as the minimum official salary, then, accordingly, the post becomes especially attractive in the labor market, which in turn forms a competitive environment among job applicants. Therefore, this post, even with a low range of salary increment, entails the increase of its priority in the company relative to the competitors, which can certainly serve as a powerful motivating factor for increasing the efficiency of personnel. 


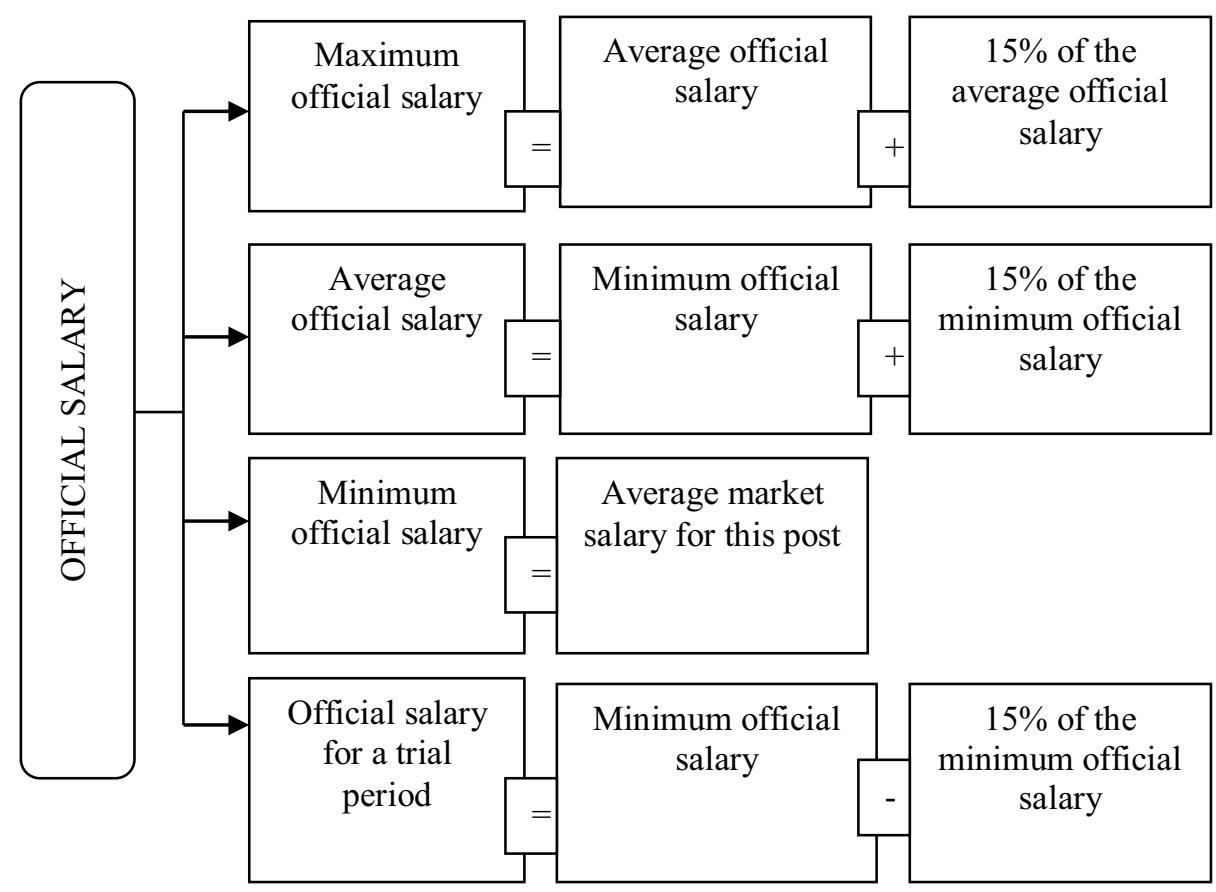

Fig. 5. The ranges of official salary

The result of the project for grading system development and implementation is basically a table with the description of all internal units including the titles of posts, their linear affiliation, subordination, grade number, integral indicators of the value of each post, belonging to the grade, salary range. Thus, the efficiency of the new remuneration system implementation in the company amounted to $6.5 \%$. The use of grading contributed to the increase of staff motivation efficiency, which ultimately led to the increase of labor productivity. As a result of grading system implementation in PAO "SZG"the labor productivity increased by $2 \%$.

\section{References}

1. Hao Wang, Jinjun Zhou, Ying T ang, Zilong Liu, Aiqing Kang, Bin Chen, Journal of $\begin{array}{llll}\text { Environment al } & \text { Management } & & \end{array}$ doi.org/10.1016/j.jenvman.2020.111701

2. Yukun Ma, Sandya Mummullage, Buddhi Wijesiri, Prasanna Egodawatta, James McGree, Godwin A.Ayoko, Ashantha Goonetilleke, Journal of Hazardous Materials 408, 124912 (2021) doi.org/10.1016/j.jhazmat.2020.124912

3. Ho Hong Lien, Yannde Mey, Simon R. Bush, Miranda P.M. Meuwissen, Aquaculture 531, 735861 (2021). doi.org/10.1016/j.aquaculture.2020.735861

4. Atsuo Murata, Safety Scie nce 135, 105091 (2021). doi.org/10.1016/j.ssci.2020.105091

5. Song-Shun Lin, Shui-Long Shen, Annan ZhoucYe-Shuang Xu, Automation in Construction 122, 103490 (2021). doi.org/10.1016/j.autcon.2020.103490

6. Jukka Hallikas, Katrina Lintukangas, Anni-Kaisa Kähkönen, Jou rnal of Cleaner Product ion 263, 121579 (2020). doi.org/10.1016/j.jclepro.2020.121579

7. Maryam Neisi, Masoud Bijani, Enayat Abbasi, Hossein Mahmoudi, Hossein Azadi, Journal of Hydrology 590, 125243 (2020). 
8. F. Brocal, N. Paltrinieri, C. González-Gaya, M.A. Sebastián, G. Reniers, Safety Science 134, 105041 (2021). doi.org/10.1016/j.jc lepro.2018.03.023

9. Jheng-Guo Chen, Yao-Zhao Zhong, Laurence Zsu-Hsin Chuang, Bärbel Koppe, Hwa Chien, Applied Geography 117, 102173, (2020). doi.org/10.1016/j.apgeog.2020.102173

10. Tarannom Parhizkara, Sandra Hogenboom, Jan Erik Vinnem, Ingrid Bouwer Utne, Safety 201, 106964 (2020). doi.org/10.1016/j.ress.2020.106964

11. VukVujović, Nebojša Denić, Vesna Stevanović, and other, Technology in Society 63, 101371 (2020). doi.org/10.1016/j.techsoc.2020.101371

12. Fatemeh Fathi, Azar Sheikhzeinoddin, Rezvan Talebnejad, Journal of Cleaner Production 258, 120772 (2020). doi.org/10.1016/j.jclepro.2020.120772

13. K.A. Barmuta, E.M. Akhmetshin, I.Y. Andryushchenko, G.V. Meshkova, A.O. Zekiy, Entrepreneurship and Sustainability 8(1), 945-959 (2020).

14. V.V. Mazur, K.A. Barmuta, S.S. Demin, E.A. Tikhomirov, M.A. Bykovskiy, International Journal of Economics and Financial 6 (1S) 270- 274 (2016).

15. K. Barmuta, V. Ponkratov, M. Maramygin, N. Kuznetsov, V. Ivlev, M. Ivleva, Entrepreneurship and Sustainability 7(1) 484-497 (2019). doi: 10.9770/jes i.7.1(34)

16. N.S. Plaskova, N.A. Prodanova, A.S. Samusenko, E.A. Erzinkyan, K.A. Barmuta, R.A. Shichiyakh, International Journal of Engineering and Advanced Technology 9 (1) 2913-2916 (2019). do i:10.35940/ijeat.A121 3.109119

17. E. Muratova, D. Muratov, E. Kravchenko, A. Sukhoveeva, O. Andreeva, E3S Web Conf. 210, 05010 (2020). doi.org/10.1051/e3sconf/202021005010

18. R. Aleshko, L. Petrova, E. Ivanova, A. Plotnikova, M. Melnikov, V. Antonov, International Journal of Engineering and Advanced Technology 9 (1), 7517-7523 (2019). doi:10.35940/ijeat.A2201.109119

19. L.V. Borodacheva, A.F. Goloborodov, A.I. Guseva, A.A. Drozdova, M.P. Glyzina, International Journal of Economics and Financial 6 (1S), 306-311 (2016).

20. A. Solonenko, L. Medvedeva and Y. Mostovaya, E3S Web Conf. 175, 13010 (2020). doi.org/10.1051/e3sconf/202017513010 